\title{
URBAN LAND-USE STUDY PLAN FOR THE NATIONAL WATER-QUALITY ASSESSMENT PROGRAM
}

\author{
U.S. GEOLOGICAL SURVEY
}

Open-File Report 96-217

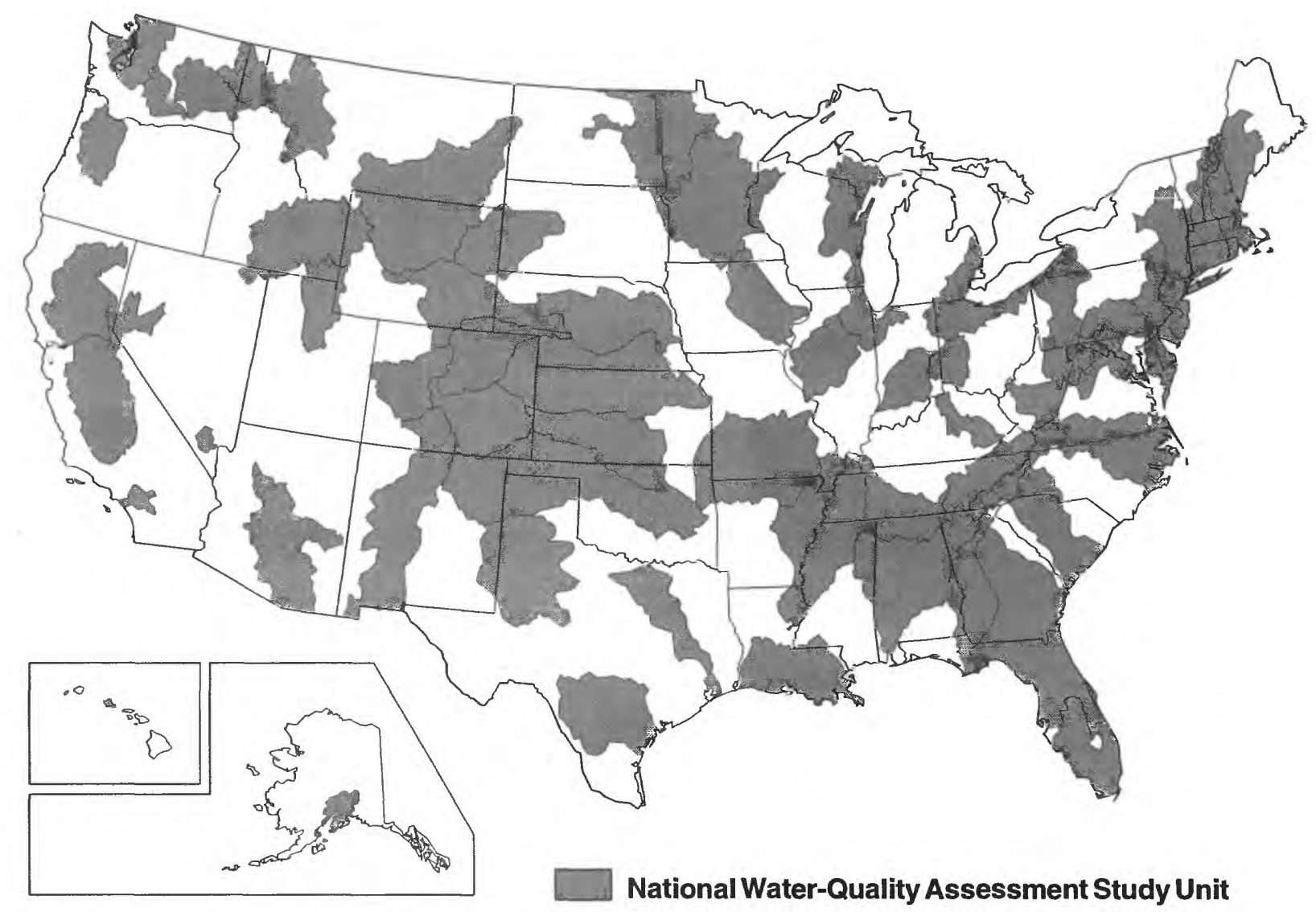

NATIONAL WATER-QUALITY ASSESSMENT PROGRAM

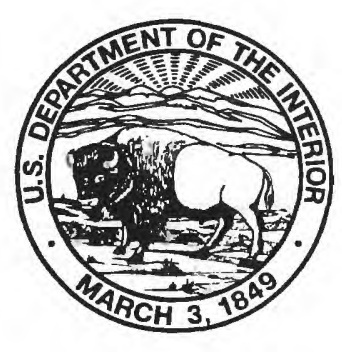


The mission of the U.S. Geological Survey (USGS) is to assess the quantity and quality of the earth resources of the Nation and to provide information that will assist resource managers and policymakers at Federal, State, and local levels in making sound decisions. Assessment of water-quality conditions and trends is an important part of this overall mission.

One of the greatest challenges faced by waterresources scientists is acquiring reliable information that will guide the use and protection of the Nation's water resources. That challenge is being addressed by Federal, State, interstate, and local water-resource agencies and by many academic institutions. These organizations are collecting water-quality data for a host of purposes that include: compliance with permits and water-supply standards; development of remediation plans for a specific contamination problem; operational decisions on industrial, wastewater, or watersupply facilities; and research on factors that affect water quality. An additional need for water-quality information is to provide a basis on which regional and national-level policy decisions can be based. Wise decisions must be based on sound information. As a society we need to know whether certain types of water-quality problems are isolated or ubiquitous, whether there are significant differences in conditions among regions, whether the conditions are changing over time, and why these conditions change from place to place and over time. The information can be used to help determine the efficacy of existing waterquality policies and to help analysts determine the need for and likely consequences of new policies.

To address these needs, the Congress appropriated funds in 1986 for the USGS to begin a pilot program in seven project areas to develop and refine the National Water-Quality Assessment (NAWQA) Program. In 1991, the USGS began full implementation of the program. The NAWQA Program builds upon an existing base of water-quality studies of the USGS, as well as those of other Federal, State, and local agencies. The objectives of the NAWQA Program are to:

- Describe current water-quality conditions for a large part of the Nation's freshwater streams, rivers, and aquifers.
- Describe how water quality is changing over time.

- Improve understanding of the primary natural and human factors that affect water-quality conditions. This information will help support the development and evaluation of management, regulatory, and monitoring decisions by other Federal, State, and local agencies to protect, use, and enhance water resources.

The goals of the NAWQA Program are being achieved through ongoing and proposed investigations of 60 of the Nation's most important river basins and aquifer systems, which are referred to as study units. These study units are distributed throughout the Nation and cover a diversity of hydrogeologic settings. More than two-thirds of the Nation's freshwater use occurs within the 60 study units and more than two-thirds of the people served by public watersupply systems live within their boundaries.

National synthesis of data analysis, based on aggregation of comparable information obtained from the study units, is a major component of the program. This effort focuses on selected water-quality topics using nationally consistent information. Comparative studies will explain differences and similarities in observed water-quality conditions among study areas and will identify changes and trends and their causes. The first topics addressed by the national synthesis are pesticides, nutrients, volatile organic compounds, and aquatic biology. Discussions on these and other waterquality topics will be published in periodic summaries of the quality of the Nation's ground and surface water as the information becomes available.

This report is an element of the comprehensive body of information developed as part of the NAWQA Program. The program depends heavily on the advice, cooperation, and information from many Federal, State, interstate, Tribal, and local agencies and the public. The assistance and suggestions of all are greatly appreciated.

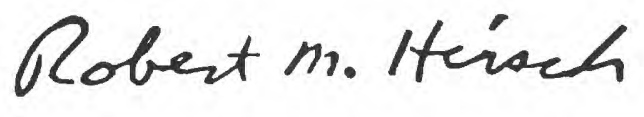

Robert M. Hirsch Chief Hydrologist 


\section{CONTENTS}

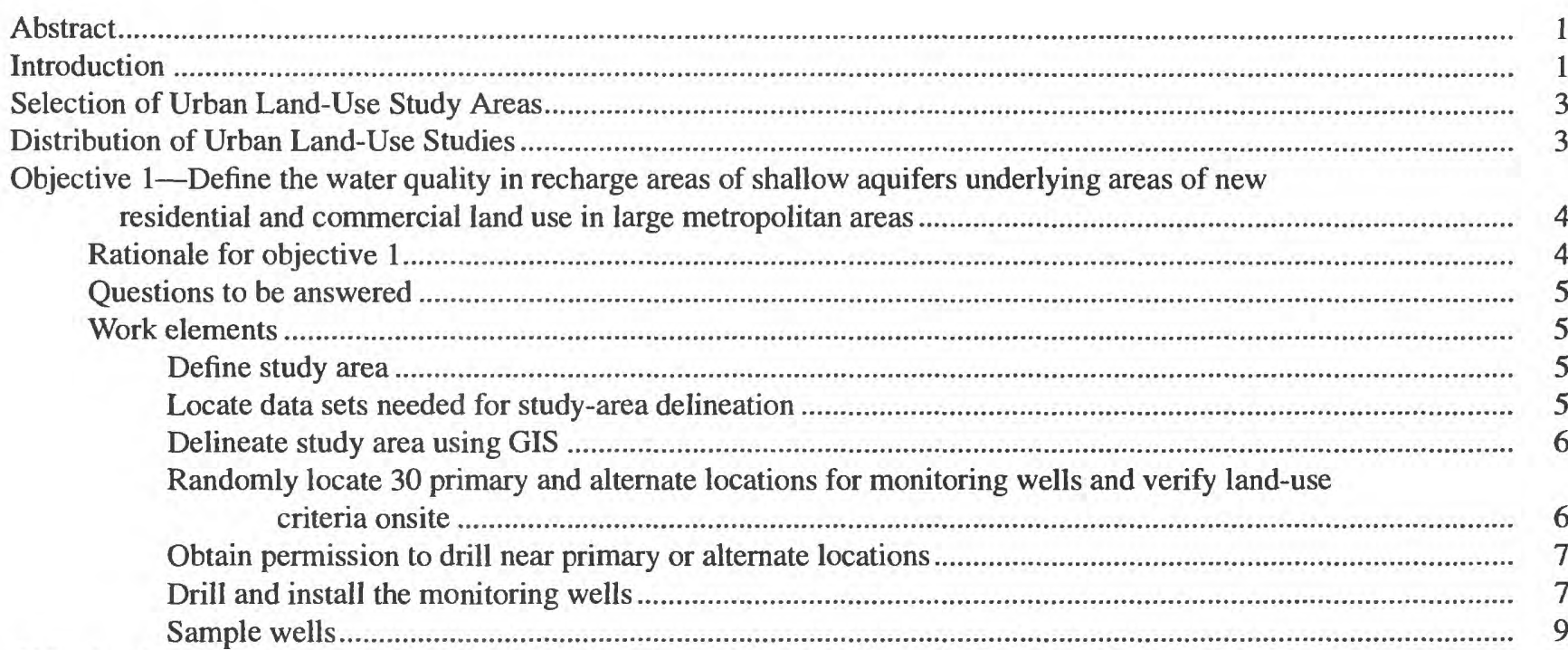

Objective 2-Collect data that will help determine which natural and human factors most strongly affect

the occurrence of contaminants beneath urban land ..............................................................................

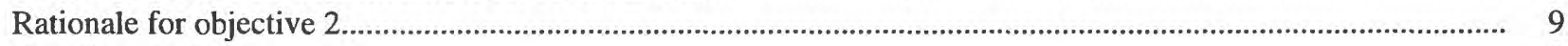

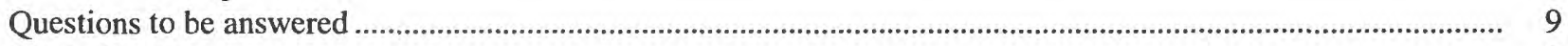

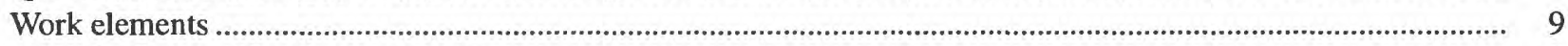

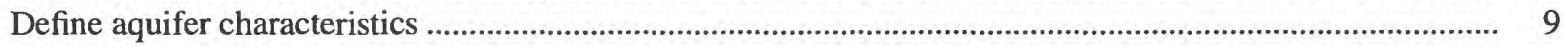

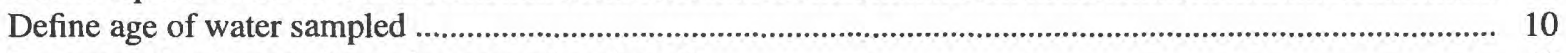

Document land-use information around each well ........................................................................... 10

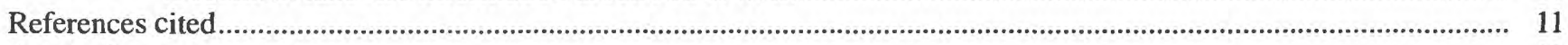

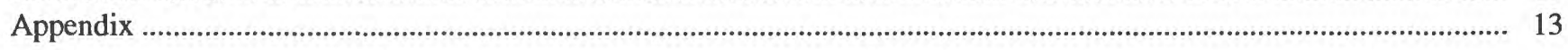

\section{FIGURES}

1. Map showing location of National Water-Quality Assessment Program Study Units and their proposed implementation dates

\section{TABLES}

1. National design matrix to distribute Urban Land-Use Studies across various climatic and hydrogeologic settings in the United States.

2. Well location and construction criteria for monitoring wells used in Urban Land-Use Studies 


\title{
Urban Land-Use Study Plan for the National Water-Quality Assessment Program
}

\author{
By Paul J. Squillace and Curtis V. Price
}

\section{ABSTRACT}

This study plan is for Urban Land-Use Studies initiated as part of the U.S. Geological Survey's National Water-Quality Assessment (NAWQA) Program. There are two Urban LandUse Study objectives: (1) Define the water quality in recharge areas of shallow aquifers underlying areas of new residential and commercial land use in large metropolitan areas, and (2) determine which natural and human factors most strongly affect the occurrence of contaminants in these shallow aquifers.

To meet objective 1, each NAWQA Study Unit will install and collect water samples from at least 30 randomly located monitoring wells in a metropolitan area. To meet objective 2 , aquifer characteristics and land-use information will be documented. This includes particle-size analysis of each major lithologic unit both in the unsaturated zone and in the aquifer near the water table. The percentage of organic carbon also will be determined for each lithologic unit. Geographic information system coverages will be created that document existing land use around the wells.

These data will aid NAWQA personnel in relating natural and human factors to the occurrence of contaminants. Water samples for age dating also will be collected from all monitoring wells, but the samples will be stored until the occurrence of contaminants has been determined. Age-date analysis will be done only on those samples that have no detectable concentrations of anthropogenic contaminants.

\section{INTRODUCTION}

The National Water-Quality Assessment (NAWQA) Program was implemented by the U.S. Geological Survey in 1991 as a systematic assessment of the quality of the Nation's water resources. The program will describe the status and trends in the quality of a large, representative part of the Nation's surface-water and ground-water resources and will define the primary natural and human factors affecting the quality of these resources. In meeting these goals, the NAWQA Program will produce information useful for policymakers, managers, and the general public at the National, State, and local levels. The building blocks of the NAWQA Program are 60 Study-Unit Investigations that include parts of most of the Nation's major river basins and aquifers (fig. 1). The proposed starting dates of the Study-Unit Investigations are staggered between 1991 and 1997. Gilliom and others (1995) discuss the overall design of the NAWQA Program in more detail.

The NAWQA study design for ground water focuses on assessing the water-quality conditions of major aquifers in each Study Unit (Study-Unit Surveys) with emphasis on the quality of recently recharged ground water associated with natural factors and human activities (Land-Use Studies). The general objective of the Land-Use Studies is to examine natural factors and human activities that affect the quality of recently recharged (generally less than 10 years old) shallow ground water that underlies key types of land 


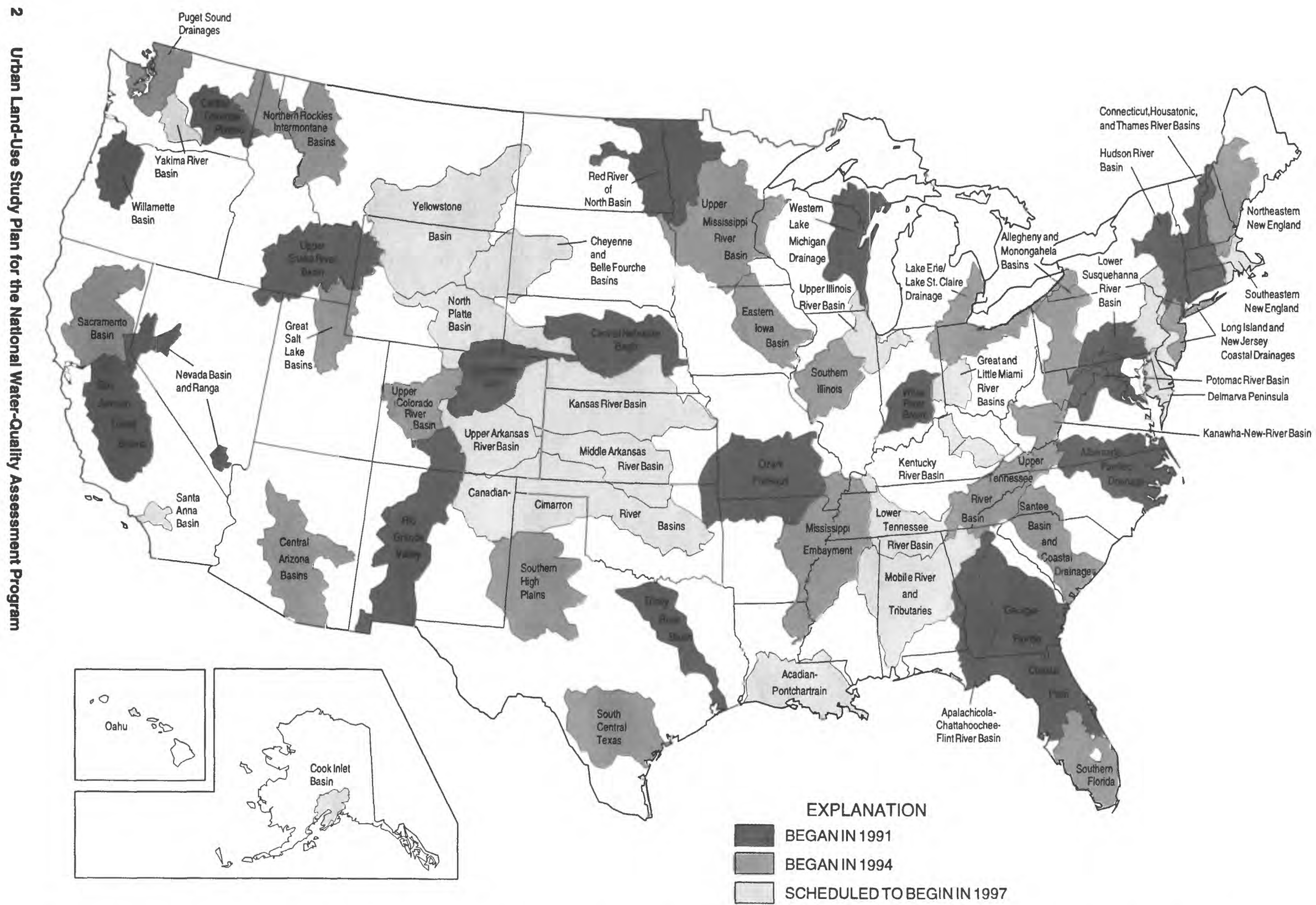

Figure 1. Location of National Water-Quality Assessment Program Study Units and their proposed implementation dates (from Gilliom and others, 1995). 
use within each Study Unit. Land-Use Studies underlying urban and agricultural settings have been the primary focus in the NAWQA Program to date.

This document provides work-element guidance for Urban Land-Use Studies to ensure consistency among the studies and applies to Study-Unit Investigations begun in 1994 or to begin in 1997. Consistency of data collection and study design is a goal of NAWQA and allows for comparison among Study Units in different climatic and hydrogeologic settings; this is necessary to address questions of national importance.

To provide a more comprehensive understanding of the water-quality issues within urban areas, it is necessary for each Study Unit with large metropolitan areas to include as many of the NAWQA's study components as possible in those areas. For example, Integrator and Indicator Surface-Water Sites, Flowpath Studies, Land-Use Studies, Sub-Unit Surveys, and Synoptic Studies as defined in Gilliom and others (1995), could all be located within urban areas. This nested study design would greatly increase the understanding of water quality in urban areas.

\section{SELECTION OF URBAN LAND-USE STUDY AREAS}

Study Units are encouraged to locate Urban Land-Use Studies in areas where shallow ground water is most vulnerable to contamination due to anthropogenic and hydrogeologic factors. Anthropogenic factors such as pesticide and nutrient use, toxic chemical use and release, and population density may contribute to the presence of contamination in shallow ground water. Large metropolitan areas with underlying shallow unconfined bedrock or sand and gravel aquifers are ideal for Urban Land-Use Studies. Hydrogeologic factors such as the amount of precipitation and thickness and permeability of the unsaturated zone also may affect the movement of contaminants to the shallow ground water.

Study Units should locate their Urban Land-Use Study in a single metropolitan area. By limiting each Urban Land-Use Study to a single metropolitan area, there is a better chance that there will be similar climate, hydrogeology, and chemical use within the study area. The effects of selected natural and anthropogenic factors on the water quality of these shallow aquifers can then be investigated. Although metropolitan areas can be very large and in some cases are adja- cent to other metropolitan areas, limiting the size of the actual study area is also necessary so that it will be easier to collect ancillary information and to create geographic information system (GIS) coverages of the study area.

Large metropolitan areas are being emphasized because population density has been related to contamination of shallow ground-water quality (Eckhardt and Stackelberg, 1995). Furthermore, 89 percent of the urban population of the United States lives in metropolitan areas of greater than 250,000 persons (U.S. Bureau of the Census, 1992). Areas with air pollution problems - that is, metropolitan areas classified by the U.S. Environmental Protection Agency as ozone or carbon-monoxide nonattainment areas-are preferred for study. Metropolitan areas with shallow ground water and permeable unsaturated zones are preferred for study. If the depth to water is great, then recharge probably would be smaller, and one would expect to see less contamination from landuse activities. There will also be some Urban LandUse Studies initiated where the unsaturated zone is not as permeable and the depth to water is variable (table 1).

The results of the Urban Land-Use Studies will be more directly relevant if the water in the shallow aquifer investigated in metropolitan areas is used for drinking. Therefore, it is preferred that the shallow aquifer in the selected metropolitan areas be (1) used as a source of drinking water, (2) considered a potential source of drinking water, or (3) hydraulically connected to surface water or deeper ground water used as a source of drinking water. If the shallow ground water does not meet the preceding criteria, then it is preferred that the aquifer be similar to aquifers that are used as a water supply in other parts of the Study Unit or region. For example, an Urban LandUse Study designed to look at natural and human effects on an alluvial aquifer in one part of the country may have transfer value to other similar areas of the country even if the ground water is not used in that particular metropolitan area.

\section{DISTRIBUTION OF URBAN LAND-USE STUDIES}

Urban Land-Use Studies are to be distributed across the United States. NAWQA plans are to conduct Urban Land-Use Studies in three general climatic settings and three general hydrogeologic 
Table 1. National design matrix to distribute Urban Land-Use Studies across various climatic and hydrogeologic settings in the United States

[The aquifers can be bedrock or unconsolidated, although drilling cost probably will necessitate that most Urban Land-Use Studies investigate unconsolidated aquifers. $\mathrm{n}=$ minimum number of Urban Land-Use Studies; $<$, less than; $>$, greater than; $\geq$, greater than or equal to]

\begin{tabular}{cccc}
\hline \multirow{2}{*}{$\begin{array}{c}\text { Annual } \\
\text { precipitation }\end{array}$} & \multicolumn{3}{c}{$\begin{array}{c}\text { Unsaturated-zone hydrogeologic } \\
\text { characteristics }\end{array}$} \\
\cline { 2 - 4 } & $\begin{array}{c}\text { Permeable } \\
\text { and } \\
<8 \text { meters } \\
\text { thick }\end{array}$ & $\begin{array}{c}\text { Permeable } \\
\text { and } \\
\text { and } \\
\text { thick }\end{array}$ & $\begin{array}{c}\text { Less permeable } \\
\text { and variable } \\
\text { thickness }\end{array}$ \\
\hline$>122 \mathrm{~cm}$ & $\mathrm{n}=2$ & $\mathrm{n}=2$ & $\mathrm{n}=1$ \\
$61-122 \mathrm{~cm}$ & $\mathrm{n}=2$ & $\mathrm{n}=2$ & $\mathrm{n}=1$ \\
$<61 \mathrm{~cm}$ & $\mathrm{n}=2$ & $\mathrm{n}=2$ & $\mathrm{n}=1$ \\
\hline
\end{tabular}

${ }^{1}$ Permeable is defined as sand and gravel with a continuous clay layer no greater than 1.5 meters thick; because these clay layers are near land surface, they are assumed to contain macropores due to fractures, roots, and so forth.

${ }^{2}$ Less permeable is defined as a continuous silt or clay layer $\geq 1.5$ meters thick.

settings of the unsaturated zone (table 1). The climatic settings are based on annual precipitation; the amount of ground-water recharge is assumed to increase as annual precipitation increases. The hydrogeologic settings are based on the permeability and thickness of the unsaturated zone; the amount of ground-water recharge is assumed to increase as permeability increases. Two studies $(\mathrm{n}=2)$ are anticipated to be conducted in each of the six categories where the unsaturated zone is permeable, and one study $(n=1)$ will be conducted in each of the three categories where the unsaturated zone is less permeable (table 1).

\section{OBJECTIVE 1-DEFINE THE WATER QUALITY IN RECHARGE AREAS OF SHALLOW AQUIFERS UNDERLYING AREAS OF NEW RESIDENTIAL AND COMMERCIAL LAND USE IN LARGE METROPOLITAN AREAS}

\section{Rationale for Objective 1}

Residential and commercial areas compose the largest land use within metropolitan areas, and little is known nationally about the associated effects of this land use on water quality. Because of the predominance of the residential and commercial land use, an understanding of the shallow ground-water quality beneath these areas is important for well-head protection of municipal and private supply wells. Also, residential areas are important because population density has been directly correlated to contamination in shallow ground water (Eckhardt and Stackelberg, 1995).

The targeted residential and commercial areas should be "new" development constructed between about 1970 and 1990. Large industrial areas and the central downtown will be excluded from the NAWQA Urban Land-Use Study. Industrial areas will not be investigated by NAWQA because some data already are being collected in these land-use areas by other Federal and State agencies. The central downtown is excluded for three reasons: (1) the ground water is generally not used in that area, (2) urban land use in that area is generally much older than 1970 , and (3) land use in that area is likely to have changed with time. If the land use has changed, the cause of contamination may be difficult to determine on the basis of current land use. Furthermore, the only national data base of land use is the land-use and landcover digital data from 1:250,000- and 1:100,000scale maps that were developed from aerial photographs taken during the 1970's and mid-1980's (U.S. Geological Survey, 1990). The data are stored in digital format called the "Geographic Information Retrieval and Analysis System" (GIRAS), which can be converted to ARC/INFO format (polygon coverage). Study Units may use a modified version of the GIRAS coverage that delineates new growth areas (Hitt, 1994); however, more detailed local information may be available. The targeted residential and commercial land-use areas should be at least 5 years old because it takes some time for new development to affect shallow ground-water quality.

A study designed to investigate new residential and commercial areas is a forward-looking plan. Older residential and commercial areas may have ground-water contamination that resulted from practices that have already been banned, and studies done in these areas may be unable to distinguish between old and new contamination problems. NAWQA study results should be helpful to resource managers and policymakers at Federal, State, and local levels in making sound decisions. There are probably three situations that most urban ground-water managers and suppliers face: (1) the existing well field lies within an 
established urban area, and they are considering expanding the well field within the established urban area; (2) the existing municipal well field lies at the edge of the urban area, and new development is beginning to encroach on the recharge area; and (3) new residential developments at the edge of the urban area have their own wells and do not use the municipal water supply. Studying the new residential and commercial areas will provide the most valuable information to city planners and municipal water suppliers in the last two situations, although some information will be helpful to municipalities in the first situation also. The information derived from Urban Land-Use Studies of new areas will provide an understanding of water-quality issues and insights on how to better plan for new developments so as to minimize water-quality degradation.

Recharge areas in the Urban Land-Use Study areas are selected for study so that a relation between land use and shallow ground-water quality can be established. Furthermore, knowledge of the shallow ground-water quality may provide an early warning of contaminants that are reaching the water table before the contaminant reaches the deeper ground water used for water supplies.

\section{Questions to be Answered}

What effect does new residential and commercial land use have on the shallow ground-water quality? Does this effect vary throughout the United States? What contaminants are commonly found in ground-water beneath new residential and commercial land-use areas?

\section{Work Elements}

\section{Define Study Area}

The study area will be defined as the intersection of two coverages: (1) the areal extent of the surficial aquifer and (2) the areal extent of the new residential and commercial land-use areas in the single metropolitan area targeted for study. The first coverage can be easily derived from the known geohydrology of the study area. The second coverage can be created using land-use, land-cover, and transportation data.
Residential and commercial land, golf courses, parks, roadways, and business highways are considered part of residential and commercial land use. Agricultural land use should be avoided or minimized in the Urban Land-Use Study area.

Industrial areas, the central downtown, and wide transportation corridors such as railway yards and limited-access highways, should be carefully excluded from the study area. Sampled monitoring wells need to be located at least $1 \mathrm{~km}$ (kilometer) from heavy industry. Light industry that is mixed with commercial areas may be very difficult to avoid and is allowed. Railways and limited-access highways consisting of two or more lanes should be excluded from the study area if they are not already excluded by the land-use coding system. This can be determined using U. S. Geological Survey digital line graph (DLG) 1:100,000-scale transportation data, or more detailed local information if available. In DLG data, railways, primary roads, and secondary roads are included in the coding system for transportation data (U.S. Geological Survey, 1989). The DLG coding system does not differentiate highways with adjoining businesses from limited-access highways, so this distinction should be done on the basis of local information.

After the study area is defined as the intersection of the geohydrology and land-use coverages, a subarea will be created for use in selecting drilling sites for monitoring wells. The selection of a subarea is necessary to avoid well sites near the edge of the study area that may be affected by features outside the study area. The residential and commercial land use, as defined previously, should make up more than 75 percent of the land use within a 500-m (meter) radius of the final drilling sites. An ARC/INFO Arc Macro Language (AML) program has been written for this purpose, and is given in the "Appendix."

\section{Locate Data Sets Needed For Study-Area Delineation}

Land-use, land-cover, and aerial photography data are available from many sources. Some useful Federal, State, and local government data sets and services include: 
1. U.S. Geological Survey 1:250,000-scale GIRAS data, updated using census population (U.S. Geological Survey, 1990; Hitt, 1994).

2. Land cover based on satellite remote-sensing data.

3. U.S. Geological Survey 1:100,000-scale DLG transportation data.

4. Census Topographically Integrated Geographic Encoding and Referencing (TIGER) system data (similar to 1:100,000-scale DLG data).

5. U.S. Geological Survey digital orthophoto quadrangles (DOQ's). DOQ's are aerial photographs registered to a map base. They are available in limited areas from the U.S. Geological Survey, State, or local agencies.

6. U.S. Geological Survey provides an aerial photography search service at Earth Science Information Centers (Denver, Colorado; Menlo Park, California; Reston, Virginia). The archive includes references to aerial photography from many agencies outside the U.S. Geological Survey. Aerial photography is available also from the U.S. Department of Agriculture, National Resource Conservation Service, and from State and local agencies.

7. Land-use, land-cover, and local-zoning maps from other sources.

\section{Delineate Study Area Using GIS}

The following six GIS processing steps are suggested to delineate the targeted study area using nationally available GIS data sets. If available, more detailed local GIS information should be used in place of the nationally available data sets.

1. Obtain updated 1990 GIRAS land-use, land-use change coverage (see Hitt, 1994).

2. Select new urban land-use areas (this is coded in the 1990 coverage as NEWLU=10). Local information should be checked at this point for accuracy, and changes or edits made, if needed.

3. Select industrial land-use areas from the GIRAS coverage (LUCODE $=13$ or 15 ) and buffer these areas by $1,000 \mathrm{~m}$.

4. Create a coverage of transportation areas (railways and nonbusiness, limited-access highways) from 1:100,000-scale DLG data.

5. From coverage (step 2), remove industrial and transportation areas (steps 3 and 4).

6. Intersect coverage (step 5) with a coverage representing the areal extent of the aquifer being studied.
7. Run SHRINK.AML (Appendix) to first select a subarea in which 75 percent of a $500-\mathrm{m}$ radius circular buffer is inside the study area and then remove areas that are within $250 \mathrm{~m}$ of the outside edge of the 75-percent area. The "75-percent" selection assures that monitoring wells are mostly affected by the target area, and the removal of edge areas allows any randomly selected site to be moved $250 \mathrm{~m}$ in any direction and preserve the 75-percent criterion.

\section{Randomly Locate 30 Primary and Alternate Locations for Monitoring Wells and Verify Land-Use Criteria Onsite}

Monitoring wells for the Urban Land-Use Study need to be distributed randomly throughout the landuse setting after the land-use areas have been delineated. It is important not to skew the locations of the wells either toward or away from possible point sources of contamination. Primary and alternate locations should be randomly selected using a computer program written by Scott (1990). This program will be used with the well-selection subarea created from the study area using the SHRINK.AML (see Appendix).

If a drill site cannot be located within $250 \mathrm{~m}$ of the primary location, then it will be necessary to move to an alternate random location. Once the primary or alternate random locations have been identified onsite, the actual drill site should be located as close to the primary or alternate random locations as possible to avoid biasing the site either toward or away from known contamination; the drill site needs to be within $250 \mathrm{~m}$ of the random location.

Drilling sites for monitoring wells must not be closer than $1 \mathrm{~km}$ from each other to avoid the overlap of buffer areas around the wells. Overlapping buffer areas may introduce spatial autocorrelation effects, which can invalidate statistical analysis of the waterquality data (Barringer and others, 1990). This minimum separation distance can be specified as input to the random site-selection program (Scott, 1990). If the delineated study area is too small to allow selection of 30 wells using this separation distance, the following approaches should be followed in this order: (1) re-evaluate the land-use and other data sets to see if more accurate data sets may generate more area; (2) alter SHRINK.AML to reduce the final $250-\mathrm{m}$ shrink or use the output area with no final shrink applied (if this is done, the actual drill site can only be moved toward the center of the study area from the 
random location); (3) run the site-selection program (Scott, 1990) with a smaller separation distance and then, after a drill site has been selected during onsite verification, iteratively disqualify random location sites that fall within $1 \mathrm{~km}$ of the drill site; and (4) add areas of slightly older development (but after 1960) to the study area (this requires local information which may be difficult to obtain).

Drill sites should be located in areas where shallow ground water originates within the designated land-use area. Therefore, drill sites can be located immediately downgradient from the selected urban land-use area.

Thirty wells is considered the minimum number of monitoring wells; some Study Units may want to install additional wells if their study area is very large. However, large study areas may encompass several cities with a variety of socioeconomic factors that may affect ground-water quality. Therefore, adjacent cities may look similar on a map, but there may be important differences that affect the occurrence and distribution of contaminants in the adjacent areas. Combining these adjacent areas into a single Urban Land-Use Study would make interpretation of the data very difficult.

\section{Obtain Permission to Drill Near Primary or Alternate Locations}

Permission to drill in residential areas may be obtained by advertising in the local paper, contacting individual landowners in person or by mail, or working closely with city and county officials or homeowner associations. Local officials that are represented on the NAWQA Study-Unit liaison committee also may be helpful in obtaining permission and may act as intermediaries between landowners and the U.S. Geological Survey. Although getting permission may be easier, the study results will not be as useful if all monitoring wells are located in a single land-use setting. For example, do not locate all wells along roads. Instead, mix well locations among church lots, school yards, edge of roads, parks, golf courses, boulevards, parking lots, private land, and so forth. An advertisement could emphasize the objectives of the NAWQA study and the need for landowners who would be willing to have 5-cm (centimeter) wells installed on their property for a long-term study of the ground-water quality. Flush-mounted monitoring wells, in some cases, can be used to minimize the inconvenience to the landowner. Names and addresses of landowners within $250 \mathrm{~m}$ of the random location point, in some situations, can be obtained from the city or county. Permission to install a monitoring well could then be requested by direct mailing to these landowners. The monitoring wells cannot be used as drinking-water or irrigation supply wells by the landowners. Permission to drill monitoring wells also may be obtained from city and State governments and the U.S. Department of Transportation.

Local or State governments may have regulations concerning the installation and sampling of monitoring wells, and the NAWQA Study Units should comply with these regulations. Furthermore, the U.S. Geological Survey form SF 9-1483 should be completed and signed by the landowner. This form specifies the rights and responsibilities of the landowner and the U.S. Geological Survey. Landowners should be informed that the water-quality results will be made available to the public, that their names will not be published in U. S. Geological publications, and that the water-quality results will be mailed to them. Landowners also should be told that some States require that the U.S. Geological Survey report any analysis with a constituent concentration that exceeds water-quality regulations.

\section{Drill and Install the Monitoring Wells}

Urban Land-Use Studies should be conducted by drilling monitoring wells rather than using existing wells. Drilling the monitoring wells provides the best control for well construction, ensures that the wells under U.S. Geological Survey ownership can be sampled in the future for trends analysis, ensures a random distribution of wells, and probably saves time and money when compared to finding existing wells in urban areas. Some NAWQA Study Units that started in 1991 spent much time trying to locate existing wells and to obtain permission to sample the well. In the end, very few could be found and the selected wells were not randomly located. Therefore, new Study Units will almost always be required to drill their own wells. By drilling wells for future Urban Land-Use Studies, NAWQA can minimize the possibility that monitoring well locations are biased toward known point-source contamination, or that the construction technique is inadequate.

In addition, in almost all cases, existing urban wells are not constructed according to NAWQA protocols and, therefore should not be sampled. Wells need to be randomly located, screened near the top of the 
water table, have flush-threaded polyvinyl-chloride casings, and be sealed. Existing monitoring wells drilled to define the upgradient conditions at a pointsource contamination site are not acceptable. Most domestic drinking-water wells normally are screened deeper in the aquifer and not at the top of the aquifer. If existing wells are used, they must meet the criteria outlined in table 2 . Use of existing wells may be allowed in the following situations: (1) If depth to water is great and the aquifer is bedrock, domestic wells may be sampled because drilling new wells would be cost-prohibitive; and (2) if a network of monitoring wells satisfies the requirements in table 2 .

Each monitoring well installed for Urban LandUses Studies should have a short screened interval (ideally less than $3 \mathrm{~m}$ in length). Generally, the top of the screen should be 0.6 to $1.5 \mathrm{~m}$ below the lowest anticipated position of the water table to reduce the chances of the well being dry during parts of the year and to avoid problems with interpreting data from wells with partially saturated, open intervals.

The 5-cm monitoring wells installed for Urban Land-Use Studies should be drilled following the guidelines outlined by Lapham and others (1995). Wells should be installed using a hollow-stem auger in unconsolidated material. Auger drilling is the most suitable drilling technique because no drilling fluids are introduced into the aquifer. Air-rotary drilling is not advisable because air compressors use oils that may be introduced into the aquifer. Mud-rotary drilling introduces mud into the aquifer.

Table 2. Well location and construction criteria for monitoring wells used in Urban Land-Use Studies

\section{Well location}

(1) Wells are located in residential and commercial areas developed between about 1970 and 1990.

(2) Monitoring-well locations are randomly distributed throughout the occurrence of the land-use setting (combination of land-use and hydrogeologic setting) of interest. Selected wells need to be located within $250 \mathrm{~m}$ of the random location identified using a computer program developed by Scott (1990). An existing network of randomly distributed monitoring wells can be sampled.

(3) Only wells located in recharge areas, underlying or immediately downgradient from the land use of interest are selected.

(4) Monitoring wells that were installed to detect a known or suspected contaminant are not selected. Even wells directly upgradient of these contaminant areas are not suitable for sampling.

\section{Type of well}

(1) Wells are observation, monitoring, or small-capacity water-supply wells to avoid the complexities of determining contributing areas to large-capacity wells (Lapham and others, 1995).

(2) Wells can be pumped at a rate that is adequate for sampling-typically, on the order of at least 0.06 liters per second.

\section{Well construction}

(1) Wells have short open intervals, generally 3 meters or less in length. The hydrogeologic unit represented by the water level being measured is known; the hydrogeologic unit contributing water to the well is known. The screened interval of the well is located beneath the top of the water table.

(2) Well-casing material is polyvinyl chloride (PVC) or stainless steel, and wells that are constructed of PVC have threaded, not glued, joints.

(3) Well screens are continuous-slot, wire-wound screens or machine-slotted casing made of PVC or stainless steel.

(4) Well construction and annular seals are sufficient to prevent infiltration of surface runoff from land surface.

(5) The integrity of well construction is assured using verification checks where practical, such as depth-to-bottom measurements.

(6) The well construction and pumping equipment in the well are known to be of a type that is not likely to affect the water-quality constituents of concern. For existing wells with pumps, only those with submersible pumps are selected. Wells with water-lubricated pumps are selected; no wells are selected with oil-lubricated, suction-lift, or gas-contact pumps.

(7) The sampling point is located before any water treatment, pressure tanks, or holding tanks.

Well-log information

(1) A well log of the lithologic units is required.

(2) Particle-size analysis and organic carbon content of major lithologic units is very desirable. 


\section{Sample wells}

Study Unit personnel will collect standard quality-control and quality-assurance samples and standard ground-water quality samples, however, it is recommended that a total of six field-blank samples be collected ( 20 percent of the 30 ground-water samples collected in an Urban Land-Use Study). Previous protocol required two to three samples (Koterba and others, 1995), but recent Urban Land-Use Studies have shown that this number of field blanks were inadequate to verify the ground-water data. To better quantify the type and potential magnitude of contamination bias, collect the six field-blank samples beginning with the 1st, then 6th, 12th, 18th, 24th, and 30th ground-water sample. To better relate contamination bias to possible site conditions, arrange the order of sampling sites so that the field blanks are collected at diverse site conditions.

Chemical analysis may include, but are not limited to, major ions, nutrients, pesticides, volatile organic chemicals (VOCs), and tritium which is discussed under objective 2. Sampling procedures have been described by Koterba and others (1995).

\section{OBJECTIVE 2-COLLECT DATA THAT WILL HELP DETERMINE WHICH NATURAL AND HUMAN FACTORS MOST STRONGLY AFFECT THE OCCURRENCE OF CONTAMINANTS BENEATH URBAN LAND}

\section{Rationale for Objective 2}

Once contaminants have been identified, defining the source of contamination is of critical interest. In past Urban Land-Use Studies, little has been done to define the source of contamination. Therefore, more detailed ancillary data will be collected for future Urban Land-Use Studies to help define the source of contamination.

Natural and human factors affect the occurrence of contaminants in shallow aquifers. Natural factors, such as the organic carbon content of the aquifer material, may limit the amount of contamination detected in shallow ground water. Human factors, such as proximity to commercial areas and highways, may explain the presence or absence of contaminants at a particular location. Within the residential and commercial land- use area, there are many potential sources of contamination, but there may be certain land-use activities that are major contributors of contaminants to shallow ground water. For example, ground-water contamination in residential areas may be related to the use of pesticides by homeowners or the release of VOC's by certain industries; industrial areas may contribute VOC's to other land-use areas via air emissions, stormwater runoff, and ground-water flow.

It is also important to determine how climate affects the shallow ground-water quality given the same land use and similar aquifers. This knowledge could help indicate if uniform Federal regulations for ground-water quality monitoring are appropriate for all parts of the United States or if such monitoring might be better tailored to climatic regions. Furthermore, the knowledge gained could help guide future land development in certain areas of the United States to protect the water quality of shallow aquifers that contribute to drinking-water supplies.

\section{Questions to be Answered}

What natural and human factors most effectively explain the presence or absence of contaminants in shallow ground water? In which setting(s) (hydrologic, geologic, climatic, land use, and so forth) are contaminants most commonly detected? What is the relation between natural factors and the quality of shallow ground water underlying key types of urban land use? Are contaminants less likely to be detected in older waters? What are the possible human sources of contamination in shallow urban ground water? What are the relations between nutrient and pesticide use, toxic chemical release, and the detection of contaminants in shallow urban ground water? Are point or nonpoint sources of contamination the greatest threat to water quality in urban areas?

\section{Work Elements}

\section{Define Aquifer Characteristics}

Aquifer characteristics, such as percentage of organic carbon, type of aquifer, particle size, and soil $\mathrm{pH}$, should be documented for each monitoring well. When drilling the wells, all drill cuttings will be logged, and split-spoon samples will be collected from all major lithologic units and the screened interval for analysis of grain size, organic carbon content, and soil 
$\mathrm{pH}$. It is expected that about three split-spoon samples per well location will be collected.

Dry-sieve analyses is recommended and can be obtained from the U.S. Geological Survey in Iowa City, Iowa, for $\$ 45.00$ (1996 cost); although any laboratory that uses standard U.S. Geological Survey procedures (Guy, 1969) can be used. About 200 to $300 \mathrm{~g}$ (grams) of sediment should be collected. Lithologic-unit samples can be stored in a freezer while a subsample is sent in for analysis of percentage of organic carbon (Powell and others, 1989).

Analysis of organic carbon, to a reporting level of 0.01 percent, can be obtained by requesting schedule 2503 from the U.S. Geological Survey National Water Quality Laboratory in Arvada, Colorado. However, the results will be meaningful only if the sample has not been contaminated by drilling fluids. The laboratory needs $10 \mathrm{~g}$ of sample for analysis collected in a wide-mouth, 500-mL (milliliter), amber, baked-glass jar. The sample should be chilled or frozen until analysis. These data are important because the fraction of organic carbon controls the sorption of organic chemicals and because the data for the deep part of the unsaturated zone and for the aquifer are not available from other data bases. It is not necessary to sample the uppermost soil horizon at the well site because information on organic carbon content can be obtained from the U.S. Department of Agriculture's Natural Resource Conservation Service county survey reports. To obtain the organic carbon content of the soil, first locate the monitoring-well site on the appropriate Natural Resource Conservation Service map and determine the soil type. The percentage of organic carbon of the soil (given as a range) can be found with the soil description in the same report.

Soil $\mathrm{pH}$ is obtained by mixing $5 \mathrm{~g}$ of soil with $5 \mathrm{~mL}$ of distilled water for 10 minutes and measuring the $\mathrm{pH}$ with a $\mathrm{pH}$ meter. This measurement is important because the degradation of methyl tert-butyl ether (commonly detected in shallow ground-water in urban areas) and ethyl tert-butyl ether occurs only in soil with small organic matter content and with a $\mathrm{pH}$ of about 5.5 (Yeh and Novak, 1994). It is strongly suggested that borehole-geophysical logging (such as gamma and electromagnetic logging) be performed on all monitoring wells. This information will improve understanding of the geology at the well site.

Other information, such as depth to the water table, depth of screen below land surface, estimated annual recharge, and presence of confining units also need to be documented for each well. If available, a water-table map showing equal water-level contours should be provided in an ARC/INFO coverage for a $500-\mathrm{m}$ radius around the well, similar to land-use information discussed in a later section of this report. A polygon coverage showing surficial geology, soil map, and bedrock geology should also be obtained.

\section{Define Age of Water Sampled}

Water samples for age dating, based on concentrations of tritium, should be collected from all monitoring wells, but the samples should be stored until the concentrations of contaminants have been determined. Age-date analysis should be done using U.S. Geological Survey lab code 624 (at a 1996 cost of about $\$ 210$ per sample) for samples which have no contamination. This analysis will define the age of the water relative to 1953 - that is, pre or post 1953 . Tritium analyses will verify that the water is recently recharged water and not old water where one would not expect to find contamination. There are other methods of age dating, such as using concentrations of tritium/helium and Freon ${ }^{\circledR}$, that have been recommended by Lapham and others (1995). These other methods have the potential to actually date the age of the water to a specific year. The best method of age dating for each Land-Use Study should be discussed between Study Unit personnel, National Synthesis Teams, and the National Leadership Team.

According to the U.S. Geological Survey's National Water Quality Laboratory (NWQL) Technical Memorandum 95.11, all tritium samples (lab code 624) are to be sent directly to the U.S. Geological Survey, Water Resources Division, Attn: Bob Michel, MS 434, 345 Middlefield Road, Menlo Park, California 94025. Analytical Services Request (ASR) forms are to be sent with the samples. After logging in the samples in Menlo Park, copies of the ASR forms will be sent to the NWQL. Bottles should be completely filled so that no air is in the bottle and the screw caps secured with tape. Requests for bottles for tritium analysis or more information can be made by email (tritium@usgs.gov).

\section{Document Land-Use Information Around Each Well}

Land-use information covering the Urban LandUse Study area will be documented by creating ARC/ INFO coverages from a variety of sources. Because the monitoring wells will not be spread across large 
areas, a single coverage should be applicable for all urban wells. At a broad scale, coverages such as land use are available from U.S. Geological Survey's National Mapping Division and can be developed from satellite data. For a smaller area, coverages such as locations of gas stations can be compiled at a scale of 1:24,000. Locations can be determined onsite using global positioning systems and aerial photography.

The following coverages should be created:

1. Point coverage showing possible contaminantrelease areas-for example, gas stations, dry cleaners, underground storage tanks, chemical plants, aboveground storage facilities.

2. Point coverage showing locations of known contaminant-release areas-for example, leaking underground storage tanks, Toxic Release Inventory sites identified by the U.S. Environmental Protection Agency, waste-disposal ponds, landfills, oil wells, injection wells.

3. Line coverages of pipelines, roadways, hypsography, sewers, septic fields, hydrography (perennial and ephemeral streams, rivers, creeks, lined and unlined drainage ditches, ground-water drains, lined and unlined irrigation canals, natural and manmade lakes, lined and unlined reservoirs, bays or estuaries, springs, dry or wet playas).

4. Polygon coverages showing golf courses, lakes, airports, military bases, mines, and population density.

5. Polygon coverage showing industrial, commercial, residential, and highway land-use areas around each monitoring well.

\section{REFERENCES CITED}

Barringer, Thomas, Dunn, Dennis, Battaglin, W.A., and Vowinkel, E.F., 1990, Problems and methods involved in relating land use to ground-water quality: Water Resources Bulletin, v. 26, no. 1, p. 1-9.

Eckhardt, D.A.V., and Stackelberg, P.E., 1995, Relation of ground-water quality to land use on Long Island, New York: Ground Water, v. 33, no. 6, p. 1019-1033.
Gilliom, R.J., Alley, W.M., and Gurtz, M.E., 1995, Design of the National Water-Quality Assessment Program-Occurrence and distribution of water-quality conditions: U. S. Geological Survey Circular 1112, 33 p.

Guy, H.P., 1969, Laboratory theory and methods for sediment analysis: U.S. Geological Survey Techniques of Water-Resources Investigations, book 5, chap. $\mathrm{Cl}$, $58 \mathrm{p}$.

Hitt, K.J., 1994, Refining 1970's land-use data with 1990 population data to indicate new residential development: U.S. Geological Survey Water-Resources Investigations Report 94-4250, 15 p.

Koterba, M.T., Wilde, F.D., and Lapham, W.W., 1995, Ground-water data-collection protocols and procedures for the National Water-Quality Assessment Program--Collection and documentation of waterquality samples and data: U.S. Geological Survey Open-File Report 95-399, 113 p.

Lapham, W.W., Wilde, F.D., and Koterba, M.T., 1995, Ground-water data-collection protocols and procedures for the National Water-Quality Assessment Program--Selection, installation, and documentation of wells, and collection of related data: U.S. Geological Survey Open-File Report 95-398, 69 p.

Powell, R.M., Bledsoe, B.E., Curtis, G.P., and Johnson, R.L., 1989, Interlaboratory methods comparison for the total organic carbon analysis of aquifer materials: Environmental Science and Technology, v. 23, no. 10, p. 1246-1249.

Scott, J.C., 1990, Computerized stratified random siteselection approaches for design of ground-waterquality sampling network: U.S. Geological Survey Water-Resources Investigations Report 90-4101, $109 \mathrm{p}$.

U.S. Bureau of the Census, 1992, Statistical abstract of the United States (112th ed.): Washington, D.C., 979 p.

U.S. Geological Survey, 1989, Digital line graphs from 1:100,000-scale maps, Data user guide 2: Reston, Va., U.S. Geological Survey, 88 p. 1990, Land use and land cover digital data from 1:250,000-and 1:100,000-scale maps, Data user guide 4: Reston, Va., U.S. Geological Survey, 25 p.

Yeh, C.K., and Novak, J.T., 1994, Anaerobic biodegradation of gasoline oxygenates in soils: Water Environment Research, v. 66, no. 5, p. 744-752. 
12 
APPENDIX 


\section{Program code for SHRINK.AML}

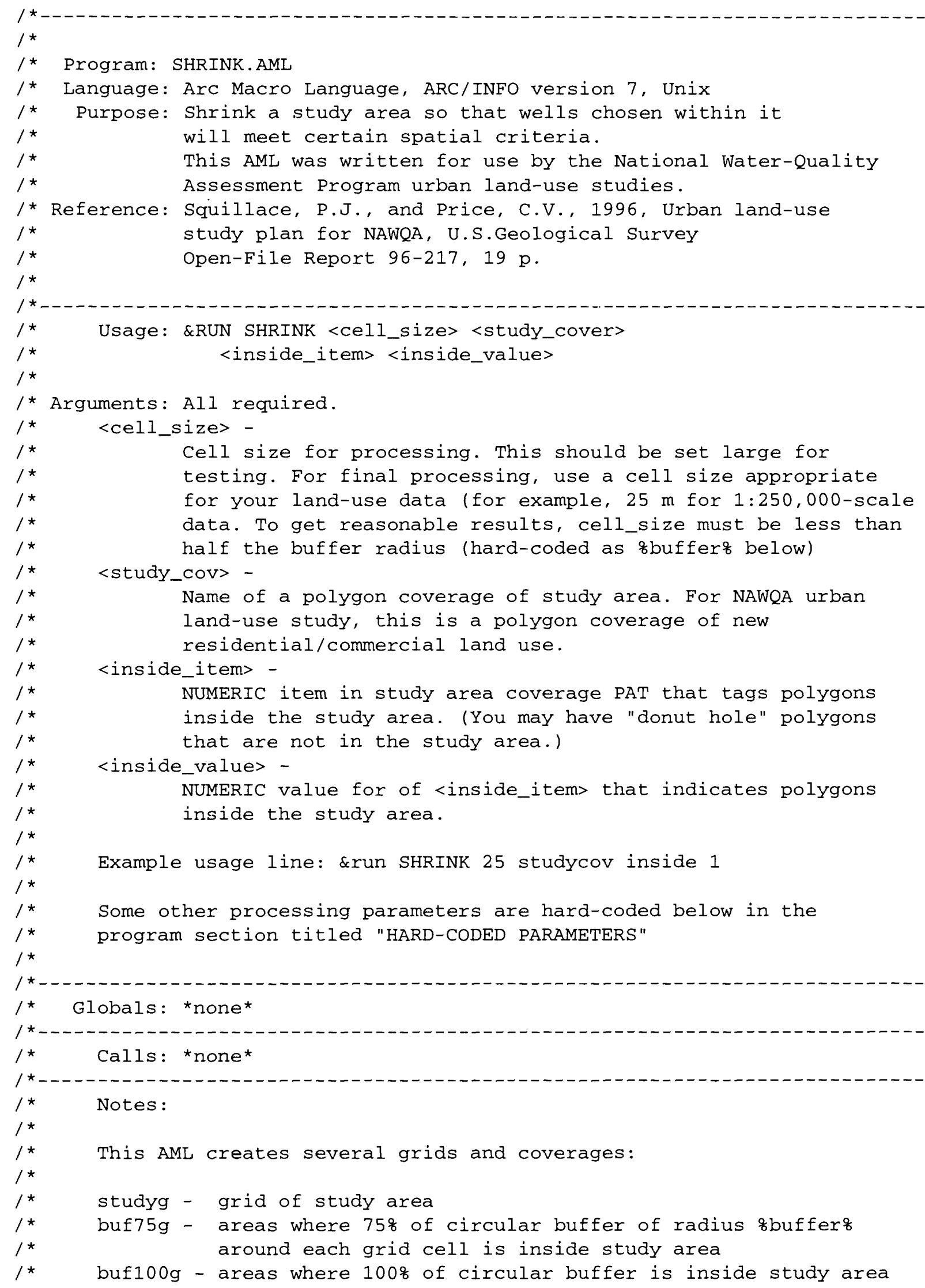




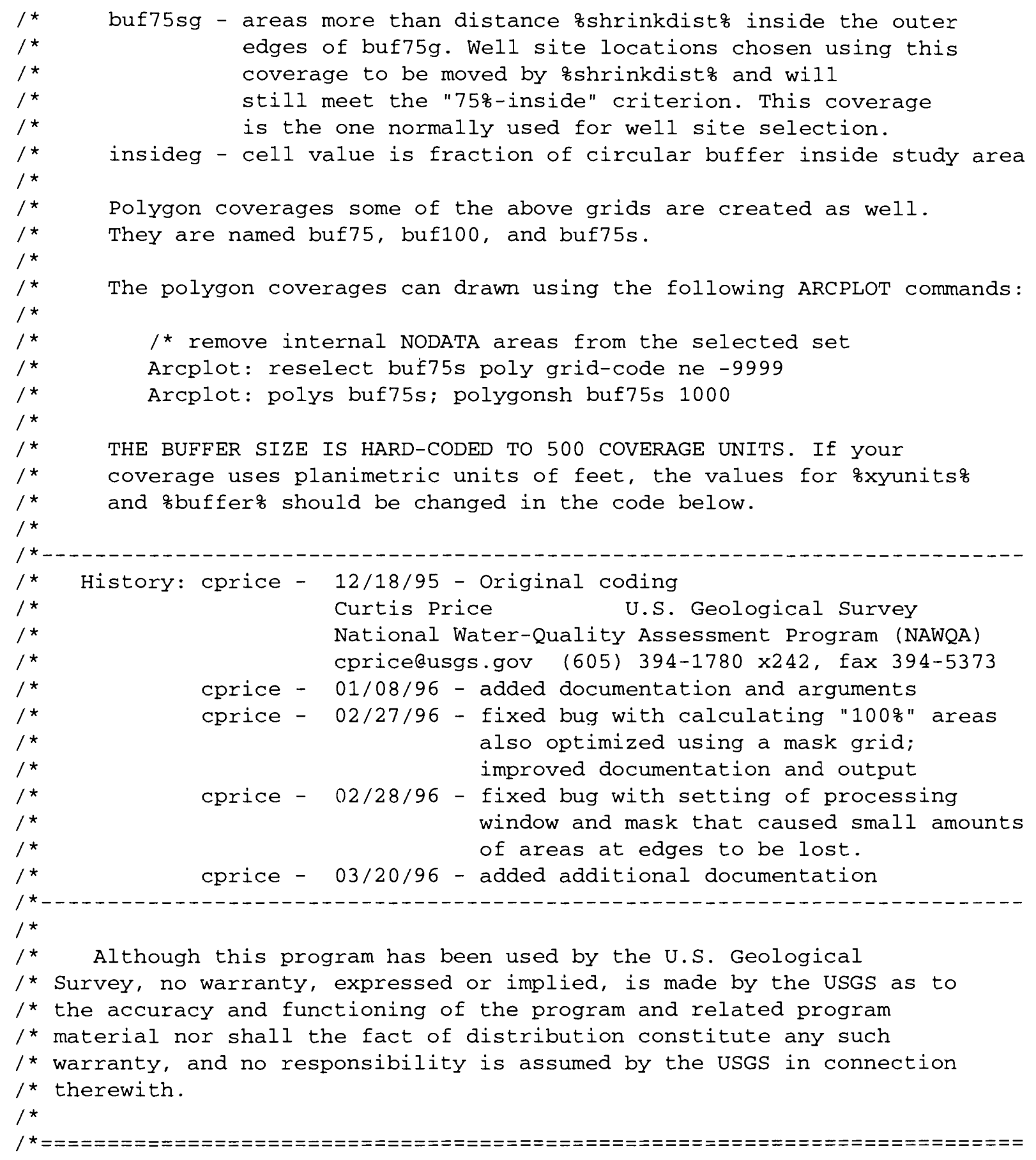

\&args cell study_cov insideitem inside

\&type '[SHRINK. AML 3/20/96]'

\&S usg Usage:

\&run shrink <cell_size> <study_cover> <inside_item> <inside_value>

\&if [show program]_ ne GRID_ \&then

\&return This AML must be run in GRID.

/* check arguments

\&if [null oinsideq] \&then \&return ousgo 
\&if [type ocello] ge 0 \&then \&return ousgo

\&if ^ [exists 8study_covo -poly] \&then

\&return Polygon coverage ostudy_covo not found.

\&s insidetype [extract 3 [iteminfo ostudy_covo -poly ofinsideitem 8 -def]]

\&if [null ginsidetypeq] \&then

\&return Item ginsideitem not found in [translate 8 study_covo]. PAT

$\backslash$ ofusgo

\&if oinsidetypes not in $\left\{I^{\prime},{ }^{\prime} F^{\prime}\right\}$ \&then -

\&return Item zinsideitem in [translate \&study_cov\&]. PAT

is not a numeric item. $\backslash$ \&usgo

\&if [type $z$ inside 8 ] ge 0 \&then sreturn <inside_value> not a number. $\backslash$ zusg $\%$

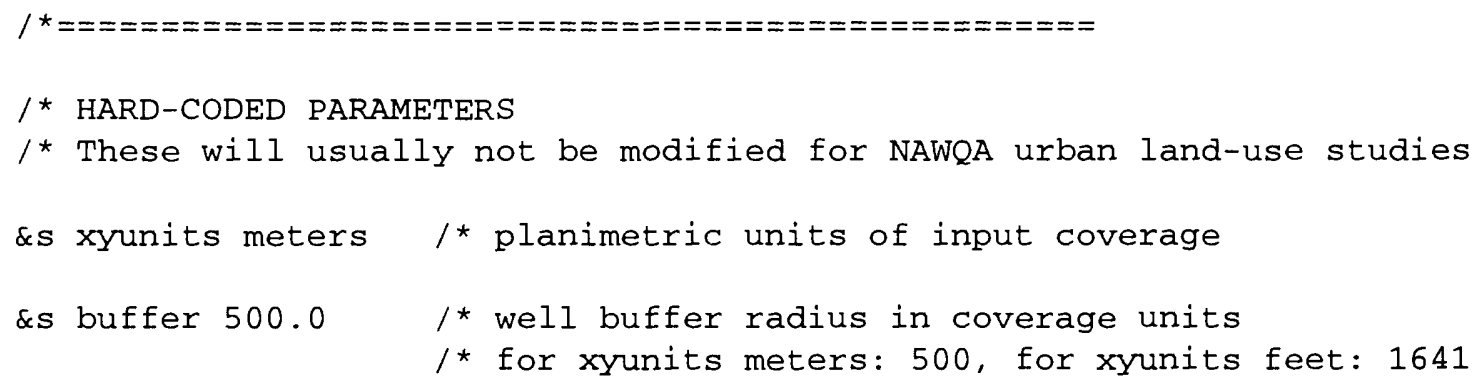


\&s bufcel1_area fgra\$zmax 8

setwindow $\%$ sw $/$ * back to our study area window

/* Create processing mask to speed up processing

/* Areas outside the mask are not processed

t_maskg = expand (studyg, [calc $1+$ fbufcellsq * 2], 1ist, 1)

setmask t_maskg

I* create "percent inside" grids

\&type ** Calculating percent inside the study area for all grid cells

insideg $=\sim$

focalsum (

con (isnull (studyg), 0,1),

circle, foufcellso, nodata)

/ float ( $\%$ bufcell_area $\%$ )

setmask off

\&type ** 'Finding $75 \%$ area'

buf75g $=$ con (insideg ge $.75,1$ )

\&type ** 'Finding $100 \%$ area'

bufloog $=$ con (insideg ge $1.0,1$ )

/* Remove areas close to the edge of the processing grid

\&type ** Finding area $>=$ oshrinkdisto units from edge of 75 [unq ' $\%$ '] area buf75sg $=\operatorname{con}(\sim$

eucdistance ( con (isnull(buf75g),1) ) ge \&shrinkdist 8 ,

1)

/* Convert grids to polygon coverages

\&type ** Creating coverages from grids

\&s weed [calc ocello * 0.2$]$

buf75 $=\operatorname{gridpoly}(\operatorname{con}($ not isnull (buf75g), 1), \&weed 8 )

buf100 = gridpoly (con (not isnull(buf100g), 1), ofweed

buf75s = gridpoly (buf75sg, ofweed 8 )

/* Delete temporary grids

kil1 (!t_buflg t_bufg t_maskg!) all

I* Report results

$\&$ s pt [show \&pt all]

$\&$ ty

\&ty Processing completed [date -cal] [extract 1 \&pt $\%$ ] 


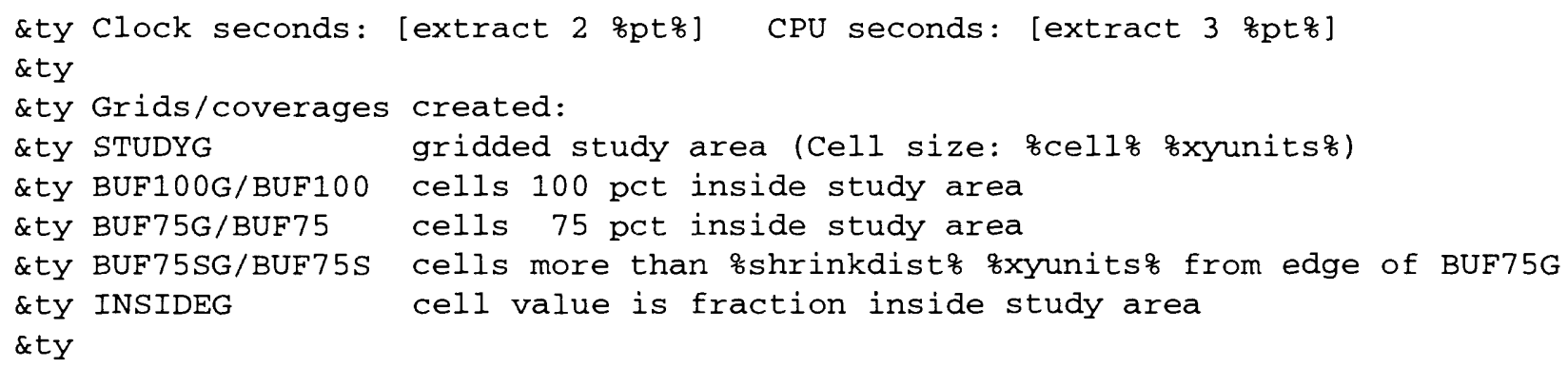

